\title{
Design, Development and Performance Evaluation of a Solar Tunnel Dryer with Reflector for Drying of Agro Food Products
}

\author{
Ronak Bagri* and Deepak Sharma \\ Department of Renewable Energy Engineering, College of Technology and Engineering, \\ Maharana Pratap University of Agriculture and Technology, \\ Udaipur, Rajasthan 313001, India \\ *Corresponding author
}

\section{A B S T R A C T}

Keywords

Solar tunnel dryer, Mint leaves.

Reflector, Moisture content

Article Info

Accepted:

26 January 2021

Available Online:

10 February 2021
A natural convection solar tunnel dryer with reflector was designed and developed at Department of Renewable Energy Engineering, CTAE, MPUAT, Udaipur for drying of mint leaves. This article deals with basic design criteria used for the development of solar tunnel dryer with reflector and results obtained for drying of fresh mint leaves. In a batch $3 \mathrm{~kg}$ of mint leaves by mass was dried having an initial moisture content of $83.33 \%$ wet basis from which $2.5 \mathrm{~kg}$ of water is required to be removed to get final moisture content of $6.25 \%$ wet basis. A drying time of $13-14 \mathrm{~h}$ is achieved in drying with an average solar radiation of $7.37 \mathrm{kWm}^{-2}$

\section{Introduction}

India stands at second position in vegetables and fruits production in the world out of which $30 \%$ to $40 \%$ is being wasted due to lack of processing and preservation infrastructure. The purpose of drying is to preserve the material over prolonged periods of time.

A solar tunnel dryer is a tunnel like framed structure covered with ultraviolet (U.V.) stabilized polythene sheet, where agriculture and industrial products could be dried under drying chamber. The black painted coating is used as an insulating material used to reduce heat loss from dryer. The heat is transferred from absorber to air in collector and heated air from collector passes over to product and absorbs moisture from the product.

The reflector is one of the simplest, cost effective and an efficient heating system. The reflector was attached to a solar tunnel dryer to reflect additional solar radiation inside the drying chamber, so that higher temperature 
can be obtained inside dryer that result in faster drying and higher moisture removal rate. The main purpose of using reflector is to create additional draft for removing moisture, resulting in increasing overall efficiency of dryer. The placement of reflector will be in north direction of the tunnel dryer to maximize the solar radiation. The sun moves from east to west direction during the day, the south side of dryer receives maximum radiation, where as in the north direction there is limited solar radiation, so reflector helps in reflecting solar radiation to north direction wall. The direct radiations gets reflected by reflector into the drying cabinet and these radiations are absorbed by black colour plastic sheet placed inside dryer at bottom, thus increases the dryer temperature. The heat accumulated in the cabinet is used for removing the moisture from the product to be dried.

There are several advantages of using reflector in tunnel dryer:

1. Additional solar radiations will be diverted in the drying chamber and will ultimately increase the overall efficiency of dryer.

2. This type of dryer can even be used in some cloudy and semi-clear sky days.

This type of dryer have faster drying rate and higher moisture content products can also be dried in it within short time

\section{Materials and Methods}

For development and construction of dryer, those materials are selected and used which could be easily available in local market at lower rates and which can be easily repaired and maintained, and have good physical and

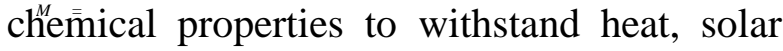
radiation, humidity of air and stress without any failure during operation.

\section{Design detail of a solar tunnel dryer with aluminum sheet reflector}

A solar tunnel dryer integrated with aluminum sheet reflector having capacity of 3 $\mathrm{kg} / \mathrm{batch}$ was designed and fabricated. The cabinet was fabricated having bottom frame size of $153 \mathrm{~cm} \times 79 \mathrm{~cm}$. The dryer length, width and height was kept $153 \times 79 \times 76 \mathrm{~cm}$. The tray of dryer was fabricated in wire mesh and having mild steel flate. The cabinet of dryer was covered with U.V. stabilized polythene film of 200 micron thickness. Two chimneys were provided on the top of the dryer for the removal of hot moist air. The chimney having dimensions of $15.24 \mathrm{~cm}$ height and $10.16 \mathrm{~cm}$ diameter were fabricated by using $2.0 \mathrm{~mm}$ M.S. sheet. Distance between two chimneys is $66 \mathrm{~cm}$. The aluminum sheet reflector of $0.763 \mathrm{~m} \times 1.52 \mathrm{~m}$ was fabricated and fixed on north side of the dryer.

By using following standard formula the initial moisture content of mint leaves was calculated.

Moisture content (w.b) $==\left(\frac{M 1-M 2}{M 2}\right) \times 100$

Where,

M1= mass of agro product in kilograms before drying, $\mathrm{kg}$

M2= mass of agro product in kilograms after drying, $\mathrm{kg}$

Moisture content of mint leaves on the dry basis is calculated by following given formula

$M d \cdot b=\frac{M w \cdot b \cdot \times 100}{100-M w \cdot b .}$ 
Where,

Md.b = on the dry basis moisture content (d.b.), $\%$

Mw.b. = on the wet basis moisture content (w.b.), \%

\section{Mass of water to be removed during drying} process (Mw)

The total mass of water in the product will be calculated by the given formula.

$\mathrm{Mw}=\frac{M i-M f}{100-M f} \times W_{t} \ldots($ Eq.3.3)

Where,

$\mathrm{Mw}=$ Mass of water to be removed during drying (kg)

$\mathrm{Mi}=$ Initial moisture content of product (w.b. $\%)$

$\mathrm{Mf}=$ Final moisture content of product (w.b. $\%)$

$\mathrm{Wt}=$ Mass of product $(\mathrm{kg})$

Total energy required for agro product drying

The total energy required for drying of mint will be calculated by using given formula.

Qreq $=[W t \times C p c(T d-T a)+(M W \times \lambda)]$

... (Eq. 3.4)

Where,

Qreq $=$ Total energy required for drying of agro product, $\mathrm{kJ}$

Cpc $=$ Specific heat capacity of agro product, $\mathrm{kJ} / \mathrm{kg}{ }^{\circ} \mathrm{C}$

$\mathrm{Td}=$ Drying temperature, ${ }^{\circ} \mathrm{C}$
Ta $=$ Ambient air temperature, ${ }^{\circ} \mathrm{C}$

$\lambda=$ Latent heat of vaporization of water, $\mathrm{kJ} / \mathrm{kg}$

$\mathrm{Wt}=$ Mass of agro product, $\mathrm{kg}$

$\mathrm{Mw}=$ Mass of water to be removed during drying, $\mathrm{kg}$

Moisture content of product during drying

The reduction in the level of moisture content of mint leaves was recorded at a time interval of 1 hour till the end of drying. By using the following equation

Moisture content (d.b.) was calculated as

Moisture content (d.b.) $=\left[\begin{array}{l}\mathrm{M}_{1}-\mathrm{M}_{2} \\ \mathrm{M}_{2} \underset{100}{\longrightarrow}\end{array}\right]$ ... (Eq. 3.5)

$\mathrm{M} 1=$ the initial weight of the sample, $\mathrm{g}$ $\mathrm{M} 2=$ the final weight of the sample, $\mathrm{g}$

\section{Energy required per hour}

By using the below formula the energy required per hour will be calculate as.

$$
\mathrm{Q}_{\mathrm{t}}=\frac{Q_{r e q}}{\mathrm{~T}_{\mathrm{d}}} \ldots(\text { Eq. 3.6) }
$$

$\mathrm{Q}_{\mathrm{t}}=$ Energy required per hour $(\mathrm{kJ} \mathrm{h})$

$\mathrm{T}_{\mathrm{d}}=$ drying time period $(\mathrm{h})$

\section{Drying rate (DR)}

The data showing the moisture content of agro product was recorded during the experiments and were analysed to determine the moisture removed from the sample of mint leaves in particular time period.

By using the following mass balance equation the drying rates of samples were calculated as 
Drying rate $=$

The total amount of moisture removed (d.b.)in $\mathrm{g} m$ total amount of dry matter in grams $\times$ Time required $(h r$.

Where,

$\mathrm{DR}=$ drying rate (gram of water evaporated / gram of dry matter/hr)

\section{Moisture ratio}

The moisture ratio of the given product is calculated by using following formula, as moisture ratio is a dimensionless quantity so it has no unit.

Moisture content (M.R) $==\frac{(M-M e)}{M 0-M e(\text { Eq. 3.8) }}$
Where,

$\mathrm{MR}=$ moisture ratio

$\mathrm{M}=$ moisture content at time $\mathrm{t}, \%$

$\mathrm{Mo}=$ Initial moisture content, $\%$

$\mathrm{Me}=$ Equilibrium moisture content, $\%$

The equation is further simplified by considering equilibrium moisture content $(\mathrm{Me})$ is very small compared with (M) and (M0) hence error associated with this are negligible. Hence therefore it can be assumed to be zero; expression is further simplified as (Gwala, 2016).

$$
\text { Moisture ratio }(\mathrm{MR})=\frac{M}{M_{0}}
$$

Total quantity of water in the material (Mtw)

The total amount of water available in the agro product can be determined by using given formula.

$$
\mathrm{M}_{\mathrm{tw}}=\mathrm{W}_{\mathrm{t}} \times \frac{\mathrm{M}_{\mathrm{i}}}{100}
$$

Where,

$\mathrm{W}_{\mathrm{t}}=$ Mass of the agro product, $\mathrm{kg}$

$\mathrm{Mi}=$ Initial moisture content of the agro product, $\%$

\section{Designing of chimney}

\section{Air required}

The quantity of air required to absorbed MW $\mathrm{kg}$ of water from product, is determined from following equations

$$
Q_{a}=\frac{M_{w} \times \lambda}{C a \times \rho a(T e-T a) \ldots(\text { Eq.3.11) }}
$$

Where, $\mathrm{Q}_{\mathrm{a}}=$ quantity of air needed to absorb moisture $\left(\mathrm{m}^{3}\right)$

$\mathrm{M}_{\mathrm{w}}=$ Total mass of water to be removed, $\mathrm{kg}$ $\lambda=$ latent heat of vaporization of water, $\mathrm{kJ} / \mathrm{kg}$ $\mathrm{C}_{\mathrm{a}}=$ Specific heat of atmospheric air, $\mathrm{kJ} / \mathrm{kg}$ ${ }^{\circ} \mathrm{C}$

$\rho_{a}=$ ambient air density, $\mathrm{kg} / \mathrm{m}^{3} \mathrm{~T}_{\mathrm{e}}=$ Moist air temperature at chimney outlet, ${ }^{\circ} \mathrm{C}$ $\mathrm{T}_{\mathrm{a}}=$ Ambient air temperature, ${ }^{\circ} \mathrm{C}$

\section{Volumetric flow rate of air}

The volumetric flow rate of air for drying of product or quantity of air needed to remove moisture in given time is calculated by using following formula

$$
\mathrm{M}_{\mathrm{a}}=\frac{\mathrm{Q}_{\mathrm{a}}}{\mathrm{t}_{\mathrm{d}}}
$$


Where,

$\mathrm{M}_{\mathrm{a}}=$ Quantity of air needed to remove moisture, $\mathrm{m}^{3} / \mathrm{s}$

$\mathrm{Q}_{\mathrm{a}}=$ air needed to absorb $\mathrm{Mw} \mathrm{kg}$ of water, $\mathrm{m} 3$

$\mathrm{t}_{\mathrm{d}}=$ drying time, $\mathrm{h}$

\section{Draft produce, Di}

The draft produced by chimney (Di) can be given by following formula.

$\mathrm{Di}=\mathrm{H} \times \mathrm{g} \times(\mathrm{pa}-\mathrm{pe}) \ldots($ Eq.3.13)

Where,

$\mathrm{Di}=$ Draft produced by chimney, $\mathrm{kg} / \mathrm{m} / \mathrm{s} 2$

$\mathrm{H}=$ Height of the chimney, $\mathrm{m}$

$\mathrm{p}_{\mathrm{a}}=$ density of inlet ambient air,

$\mathrm{kg} / \mathrm{m}^{3}$

$\mathrm{p}_{\mathrm{e}}=$ exit air density, $\mathrm{kg} / \mathrm{m}^{3}$

\section{Actual draft produced}

The actual draft which is produced by chimney is given as

$\mathrm{Da}=0.80 \times \mathrm{Di}$

Velocity of exit air at chimney outlet, V

$V=\sqrt{ } 2 \underline{D}_{\underline{a}}$

Where,

V-Velocity of exit air at chimney outlet, $\mathrm{m} / \mathrm{s}$ $\mathrm{D}_{\mathrm{a}}$ - actual draft produced, $\mathrm{kg} / \mathrm{m} / \mathrm{s}^{2}$

$p_{e}$ - exit air density, $\mathrm{kg} \mathrm{m}^{3}$

\section{Cross sectional area of chimney}

$$
A_{c h}=\frac{Q}{V \times K}
$$

\section{Diameter of chimney, Dc}

The diameter of chimney is calculated by using below formula

$D c=\sqrt{A c h \times 4} \frac{1}{\pi}$

Where,

Dc - Diameter of the chimney, $m$

$\mathrm{A}_{\mathrm{ch}}-$ Cross section area of each chimney, $\mathrm{m} 2$

\section{Detail of experimental setup principles of} drying

A solar tunnel dryer integrated with reflector system of (3 kg/batch) will be developed and installed at department of REE of CTAE, Udaipur $\left(27^{\circ} 42^{\prime} \mathrm{N}, 25^{\circ} 33^{\prime} \mathrm{E}\right)$. It consists of an aluminum sheet reflector.

The dryer was oriented east-west to maximize the solar radiation incident on the dryer. In order to evaluate performance of solar tunnel dryer following parameters were measured: temperature, solar intensity, ambient temperature, relative humidity, dryer temperature and drying time. On this basis moisture content and drying rate of product was determined. The intermittent moisture content of agro-product was measured at an interval of $1 \mathrm{hrs}$.

\section{Mechanism of solar dryer with reflector}

The direct solar radiations were reflected by reflector into the cabinet in which black colour plastic sheet is placed at the bottom. The radiations were absorbed by black plastic sheet and thus result into increased cabinet temperature. Heat accumulated in the cabinet was used for removing the moisture from the product placed inside. 


\section{Performance evaluation of solar tunnel dryer with reflector}

\section{Under no load test}

For determining the maximum potential of temperature rise in the drying chamber the no load testing was done. Experiment was conducted on solar tunnel dryer with reflector on consecutive days in the month of February 2020. The tests were carried out between time periods of $10: 00 \mathrm{~h}$ to $16: 30 \mathrm{~h}$ before the sunset, in this time period solar radiation intensity was considerable.

The maximum solar radiation inside the referenced solar dryer (without reflector) was found as $805 \mathrm{~W} / \mathrm{m} 2$ at $12: 00 \mathrm{~h}$ and minimum value of solar radiation was found to be 235 $\mathrm{W} / \mathrm{m}^{2}$. The maximum solar radiation inside the solar dryer with reflector at no load testing was found to be $790 \mathrm{~W} / \mathrm{m} 2$ at $13: 45 \mathrm{~h}$ and minimum solar radiation was $268 \mathrm{~W} / \mathrm{m} 2$ at $16: 30 \mathrm{~h}$.

\section{Full load test}

The performance of solar tunnel dryer with reflector under full loading test was conducted to determine actual loaded conditions of the dryer. Under full load testing the actual heat required to extract moisture from the raw material can be utilized in solar tunnel dryer. The material was spread on food tray in the form of a thin layer. For this only one tray is appropriate and recommended to accommodate $3 \mathrm{~kg}$ of material kept inside the solar tunnel dryer. At an interval of one hour the experiments were conducted to determine temperature and solar radiation, starting from 10:00 $\mathrm{h}$ to $17: 00 \mathrm{~h}$. The experiment was conducted in full load condition and data was recorded for hourly solar radiation, drying time, moisture content, weight reduction, moisture ratio and air temperature at different locations for calculation of drying rate based on load density of product.

In full load test the mint leaves samples were spread over the perforated sheet. The initial weight of the samples was recorded. The drying trays were loaded with $3 \mathrm{~kg}$ of mint leaves for its drying. Inside and outside air temperature, outside relative humidity were recorded at one hour interval during the test run.

It was also observed that the maximum and minimum solar radiation in month of March was $1088 \mathrm{~W} / \mathrm{m}^{2}$ at $12: 00 \mathrm{~h}$ and $346 \mathrm{~W} / \mathrm{m}^{2}$ at 17:00 $\mathrm{h}$ respectively. As compared the time taken in solar dryer with reflector was $14 \mathrm{~h}$ and time taken in open sun drying was $19 \mathrm{~h}$.

\section{Drying characteristics of mint leaves}

Most of minerals and vitamins like $\mathrm{Ca}, \mathrm{K}, \mathrm{Na}$, $\mathrm{Mg}, \mathrm{P}$ and $\mathrm{Fe}$ and vitamins like $\mathrm{A}, \mathrm{C}, \mathrm{K}$, folic acid, riboflavin thiamine and niacin are present in mint leaves (Raghavan, 2006). Mint leaves are known for their refreshing, anti-bacterial, anti-oxidental, antiseptic, antiasthmatic, stomachic properties. It is used mostly as medicinal, refreshing plant which helps in cold diseases, flu, fever, poor digestion, food poising, motion sickness and for throat problems. Mint leaves are also used for flavoring, and as spice (Chawla and Thakur, 2013)

This experiment was performed with following specific objectives:

1. To design and develop an efficient solar tunnel dryer with reflector for agro product drying.

2. To evaluate the performance of developed system.

3. To study techno economic feasibility of the developed system. 
Economic analysis of the solar tunnel drying system

The economic viability of the proposed system was calculated through economic analysis of the system. An attempt was made to evaluate economics of designed solar drying system. The economic indicator like payback period was used in computing the economics of the system. The economic analysis was carried out by considering the following assumptions (Seveda et al., 2004).

1. The solar dryer with reflector system was used to dry $3 \mathrm{~kg}$ of mint leaves per batch.

2. The total finished product was produced per batch at $6.25 \% \mathrm{wb}$.

3. The dryer can operate 312 days per year.

4. The average purchase price of freshly harvested mint leaves was Rs. 40 per kg.

5. The average selling price of the mint leaves powder was Rs 300 per kg.

6 . The cost of solar dryer with reflector was taken as Rs. $9830 /$.

7. The useful life of domestic solar dryer system was considered to be 5 years.

8. The annual repair and maintenance cost of the system was $3 \%$ of capital cost of the system.

\section{Sensory evaluation}

Sensory evaluation was carried out to estimate and evaluate the qualities of dried mint leaves produced by each drying method. For determining quality of the dried mint leaves colour, taste and flavor were the main attributes for estimating the quality and consumer acceptance of mint leaves powder produced. The overall quality of each dried sample was assessed by ten panelists.

\section{Results and Discussion}

The developed solar dryer assisted with reflector was used for drying of $3 \mathrm{~kg}$ mint leaves in a batch. The performance analysis of domestic solar dryer assisted with reflector for drying of mint leaves was computed as below:

\section{No load testing of solar dryer with reflector}

The temperature developed in the solar dryer integrated with reflector at no load condition during day time was recorded. From the experimental results it was observed that the maximum temperature obtained inside the solar tunnel dryer with reflector was $72.5^{\circ} \mathrm{C}$ at 13:30 h, while minimum temperature attained was $34^{\circ} \mathrm{C}$ at $10: 00 \mathrm{~h}$ in the month of February 2020. Maximum ambient temperature was $24^{\circ} \mathrm{C}$ at 13:00 h. From the observation it was found that there is an increment of $48.5^{\circ} \mathrm{C}$ temperature inside the solar dryer with reflector and $43.4^{\circ} \mathrm{C}$ temperature in reference solar dryer as compared to the ambient temperature. The maximum temperature attained inside reference solar dryer (without reflector) was 67.4 at $13: 30 \mathrm{~h}$, while minimum temperature attended was $35^{\circ} \mathrm{C}$ 10:00 h in month of February 2020. From the experimental data it was observed that the maximum and minimum value of ambient solar insolation in this month was $935 \mathrm{~W} / \mathrm{m} 2$ at $12: 30 \mathrm{~h}$ and $270 \mathrm{~W} / \mathrm{m} 2$ at $16: 45 \mathrm{~h}$ respectively. In solar dryer with reflector and reference solar dryer the trend of result for inside and outside solar radiation was shown as below on graph in Fig. 1.

Full load testing of solar dryer with reflector

The solar tunnel dryer with reflector was tested for drying of mint leaves. Full load testing was done in order to find out the temperature variation profile of open sun drying and solar tunnel dryer with reflector for drying of mint leaves. 
From the experiment it was observed that maximum ambient temperature obtained was $33^{\circ} \mathrm{C}$ at 15:00 $\mathrm{h}$, while minimum temperature was $28^{\circ} \mathrm{C}$ at $10: 00 \mathrm{~h}$ in the month of March 2020. In solar dryer with reflector the maximum temperature obtained was $73^{\circ} \mathrm{C}$ at 13:00 $\mathrm{h}$ and minimum temperature was found as $42^{\circ} \mathrm{C}$ at $2 \mathrm{nd}$ day of experiment. From the observation it was observed that there is an increment of $40^{\circ} \mathrm{C}$ temperature inside the solar dryer with reflector as compared to ambient temperature. It was also observed that the maximum and minimum solar radiation in month of March was $1088 \mathrm{~W} / \mathrm{m} 2$ at $12: 00 \mathrm{~h}$ and $346 \mathrm{~W} / \mathrm{m} 2$ at 17:00 $\mathrm{h}$ respectively. During the full load testing the trend of result for solar radiation and temperature in solar dryer drying with reflector and open sun drying was plotted on graph as shown in Fig. 2 and Fig. 3 respectively.

From the experimental results it was observed that the maximum temperature obtained inside the solar tunnel dryer with reflector was $68^{\circ} \mathrm{C}$ at $13: 00 \mathrm{~h}$, while minimum temperature was $46^{\circ} \mathrm{C}$ at 10:00 h. And inside the referenced solar dryer the maximum temperature obtained was $63.6^{\circ} \mathrm{C}$ at $13: 00 \mathrm{~h}$ and minimum temperature was $38^{\circ} \mathrm{C}$ at $16: 00$ $\mathrm{h}$ in the month of March 2020. The maximum and minimum ambient temperature was observed as $33^{\circ} \mathrm{C}$ and $28^{\circ} \mathrm{C}$. From the experimental results it was observed that there is an increment of $35^{\circ} \mathrm{C}$ temperature inside the solar dryer with reflector and there is an increment of $30.6^{\circ} \mathrm{C}$ temperature inside the referenced solar dryer as compared with the ambient temperature. During the full load testing of solar dryer with reflector and referenced solar dryer the trend of result for the solar radiation and temperature is plotted on graph as shown in Fig. 4 and Fig. 5 respectively.

\section{Performance evaluation of drying process} Variation of moisture content of mint leaves with respect to time in open sun drying

During the full load testing the moisture content (w.b.) of open sun drying is presented in the Fig. 6. The moisture content varies from $87.22 \%$ to $10 \%$ (wb). As compared to time taken in reflector attached solar dryer drying the time taken in open sun drying was approximately double.

As a conventional method of drying open sun drying has limitation that there is non-uniform drying of leaves and there is a chance of deterioration of agro food product by external agent. The rate of moisture evaporation from mint leaves.

\section{Moisture content variation of Mint leaves in Referenced Solar Dryer with Respect To Time}

During full load testing the moisture content (w.b.) of referenced solar dryer of UV stabilized polythene sheet. Moisture content varies from initial moisture content of $87.22 \%$ (w.b.) to final moisture $8.5 \%$ (w.b.). Moisture evaporates rapidly at time when drying of mint leaves started and then it slowed down. With increase in the drying time the moisture content was reduced (Fig. 7).

During the full load testing of solar dryer with reflector, the moisture content (w.b.) of solar dryer with reflector is presented in Fig. 8. Drying of mint leaves occurs from the initial moisture content of $83.33 \%$ (w.b.) to the final moisture content of $6.25 \%$ (w.b.) Moisture evaporated rapidly at time when drying of mint leaves started and it then slowed down after time passes. With increase in the drying time the moisture content was reduced. The moisture content variation under UV stabilized polythene sheet of 200-micron thickness in solar dryer with reflector is given. 
Techno-economic analysis of the developed solar tunnel dryer with reflector

Techno-economic evaluation and analysis is a methodology framework used to analyse the economic and technical performance of the product. Techno- economic analysis consists of combination of processes like engineering design and economic evaluation. Whereas Techno economic feasibility is study used to determine the technical feasibility and financial visibility of the project, risk associated with it, immediate actions that required to be taken.

\section{Payback period}

The payback period is defined as the Liked duration of the time required for an extreme investment made to recover its initial fund expended in it in terms of profits or saving.

In capital budgeting payback period is the time required to recoup the total income expended in an investment or to reach the break- even point. For a developed system the payback period was estimated by adding the net cash flow in the project to the cumulative net cash flow to the initial investment made. The shorter duration of payback period means the investment is more attractive.

Payback period $=$

\section{Total investment made Net profit obtained}

Table.1 Result obtained from sensory evaluation

\begin{tabular}{|c|c|c|c|c|c|}
\hline Sample & Colour & Flavour & $\begin{array}{c}\text { Appe } \\
\text { arance }\end{array}$ & $\begin{array}{c}\text { Overall } \\
\text { accepta } \\
\text { bility }\end{array}$ & Remark \\
\hline Leaves & 9 & 9 & 9 & 9 & $\begin{array}{c}\text { Liked } \\
\text { Extremely }\end{array}$ \\
\hline $\begin{array}{c}\text { Open } \\
\text { sun } \\
\text { drying }\end{array}$ & 6 & 6 & 7 & 6.33 & $\begin{array}{c}\text { Liked } \\
\text { Slightly }\end{array}$ \\
\hline $\begin{array}{c}\text { Reference } \\
\text { Solar }\end{array}$ & 7 & 6 & 8 & 7 & $\begin{array}{c}\text { Liked } \\
\text { Moderate }\end{array}$ \\
\hline $\begin{array}{c}\text { Drying } \\
\text { Solar } \\
\text { dryer } \\
\text { with } \\
\text { reflector } \\
\text { drying }\end{array}$ & 8 & 8 & 8 & 8 & $\begin{array}{c}\text { Liked } \\
\text { Mostly }\end{array}$ \\
\hline
\end{tabular}


Table.2 Design specification of the solar tunnel dryer for drying of mint leaves

\begin{tabular}{|c|c|c|}
\hline Sr.No. & Components/ Particulars & Specifications \\
\hline 1. & Covering material (Collector) & $\begin{array}{l}\text { UV stabilized polythene sheet } \\
\text { of } 200 \text { microns thickness }\end{array}$ \\
\hline 2. & Dryer orientation & $\begin{array}{c}\text { In the } \mathrm{E}-\mathrm{W} \\
\text { direction }\end{array}$ \\
\hline 3. & Size of the chimney (height and diameter) & $\begin{array}{l}152.4 \mathrm{~mm} \text { and } \\
101.6 \mathrm{~mm}\end{array}$ \\
\hline 4. & $\begin{array}{l}\text { Total Number of } \\
\text { chimneys }\end{array}$ & 2 \\
\hline 5. & $\begin{array}{l}\text { Tray size (length } \\
\text { and width) }\end{array}$ & $\begin{array}{c}1.42 \mathrm{~m} \text { and } 0.66 \\
\mathrm{~m}\end{array}$ \\
\hline 6. & $\begin{array}{l}\text { Length of solar } \\
\text { tunnel dryer }\end{array}$ & $1.52 \mathrm{~m}$ \\
\hline 7. & Breath of solar tunnel dryer & $0.76 \mathrm{~m}$ \\
\hline
\end{tabular}

Fig.1 Variation of solar radiation in solar dryer with reflector and reference solar dryer

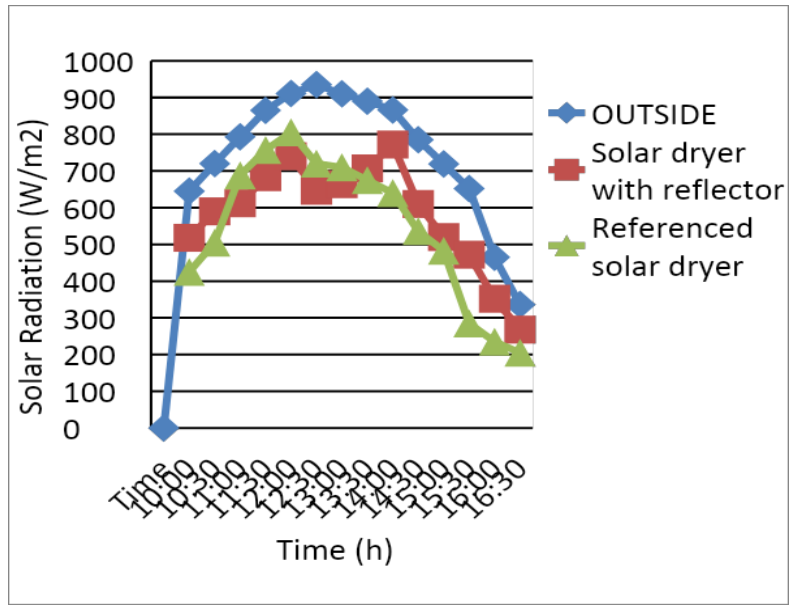

Fig.2 Variation of ambient temperature and solar radiation in open sun drying

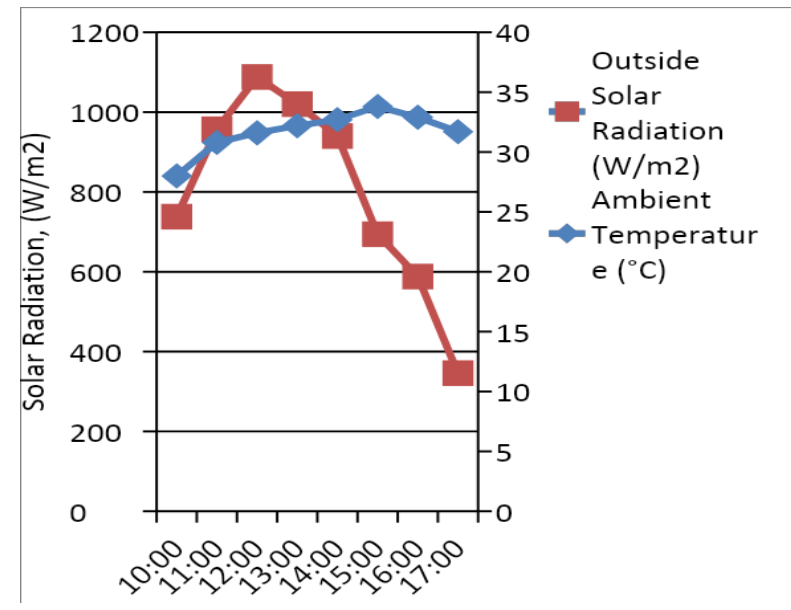


Fig.3 Solar radiation and temperature variation in solar dryer under full load testing at day 1

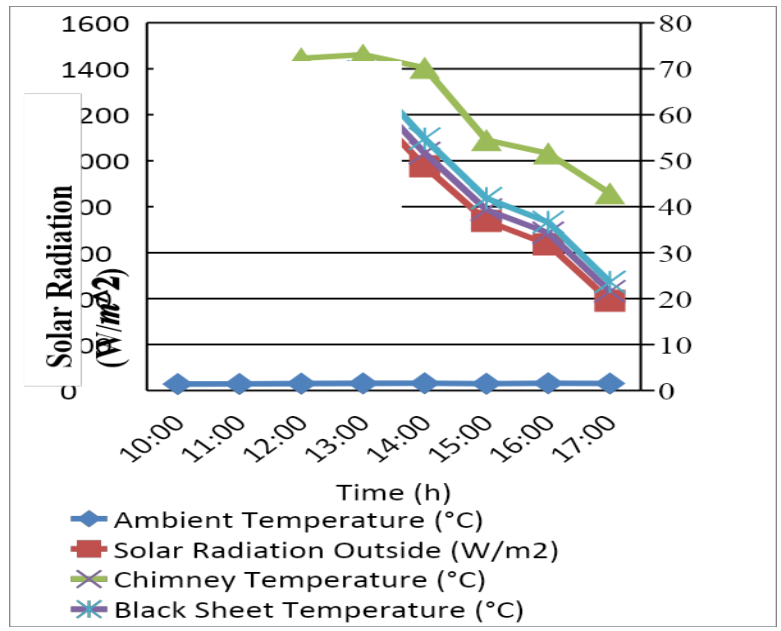

Fig.4 Full load performance curve of solar dryer with reflector

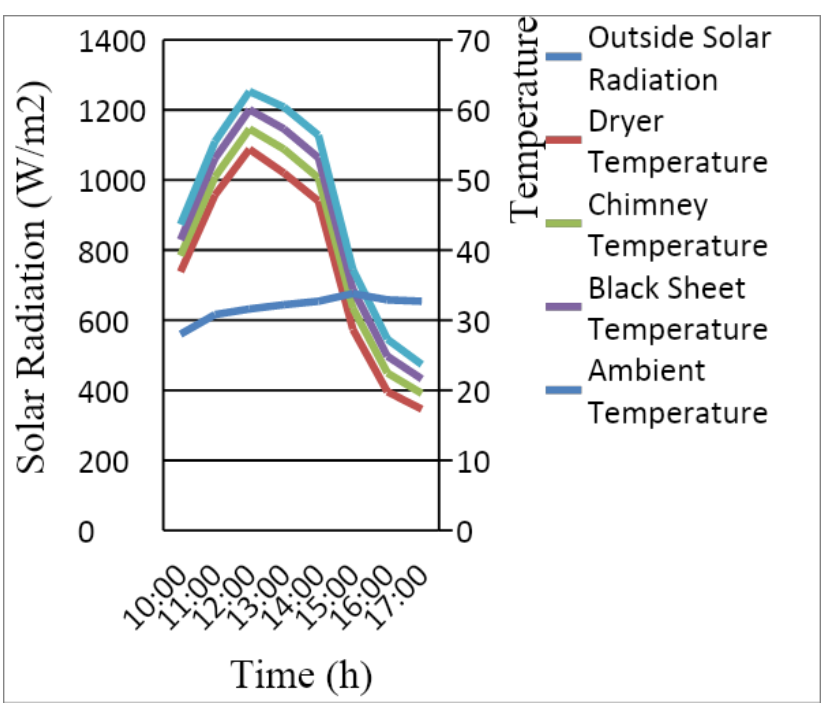

Fig.5 Full load performance curve of reference solar dryer (without reflector)

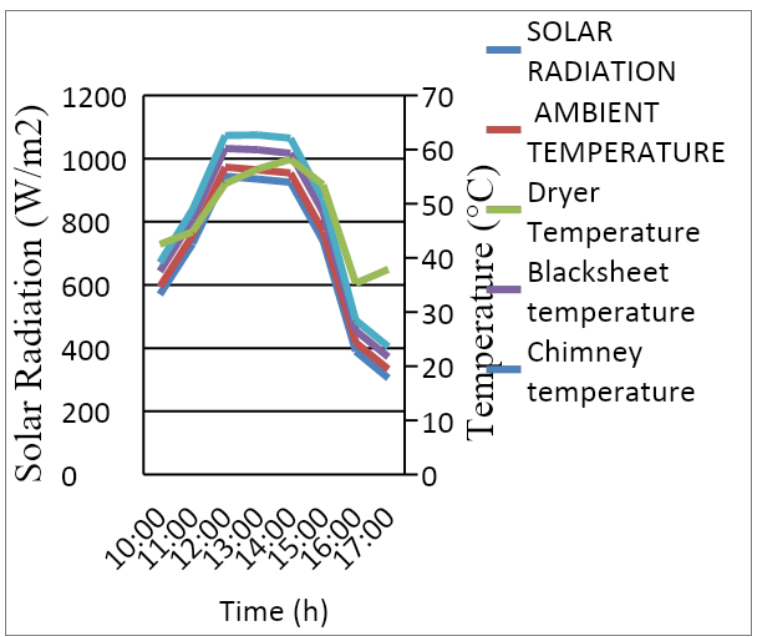


Fig.6 Variations in the Moisture Content of Mint Leaves with Respect to time taken in Solar Dryer with Reflector

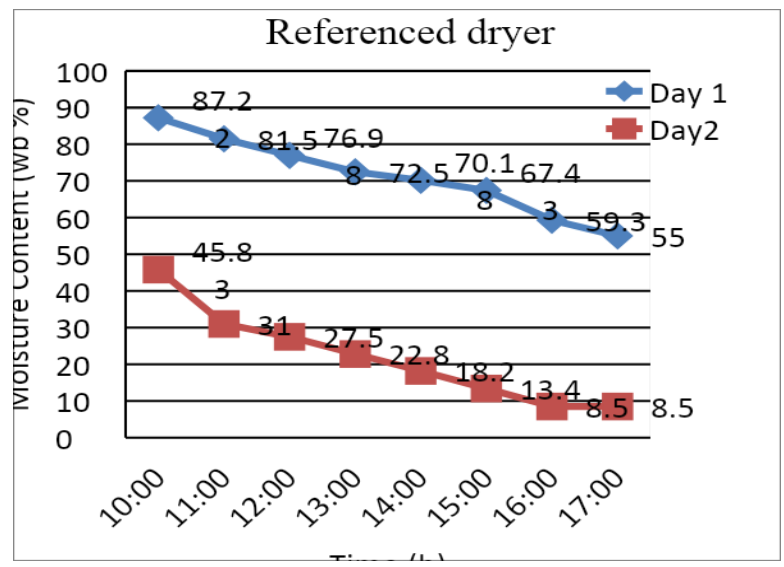

Fig.7 The variation of moisture content in solar dryer with reflector

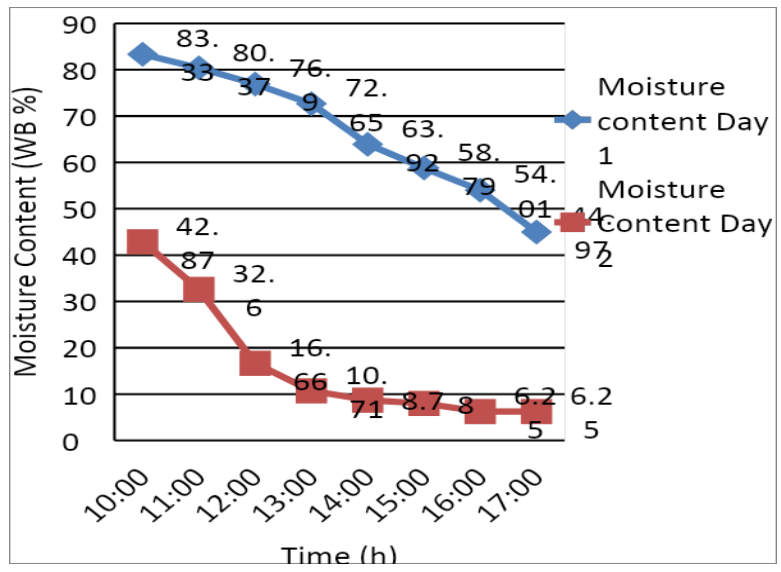

Plate 1 Full load test of dryer with reflector

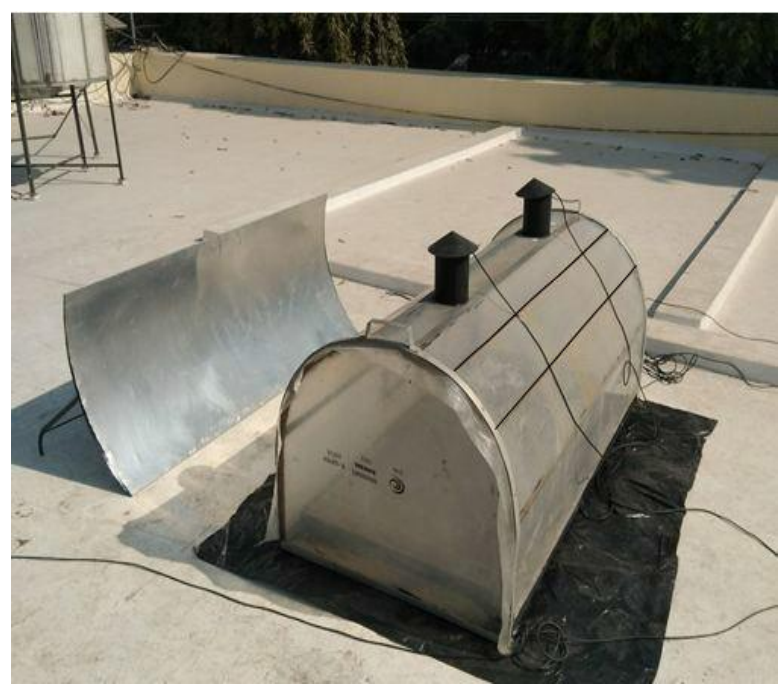


Plate 2 Fresh mint leaves

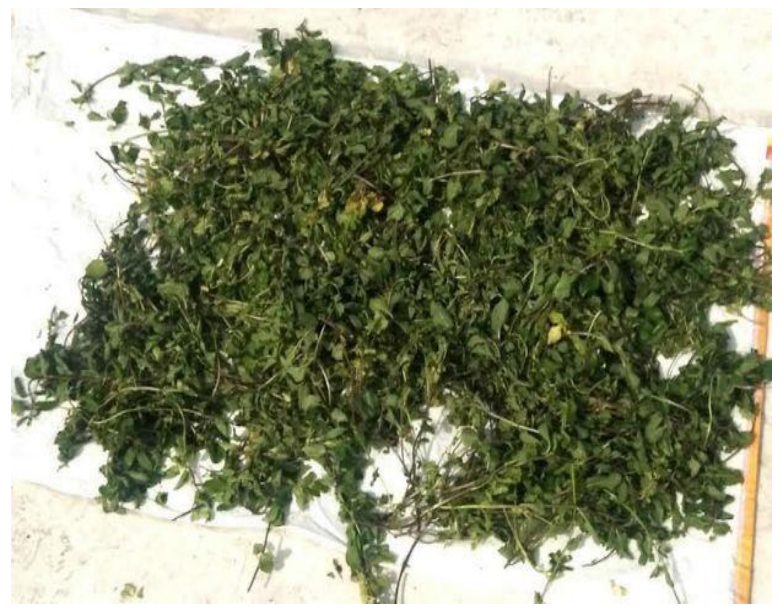

Plate 3 Dried Mint leaves

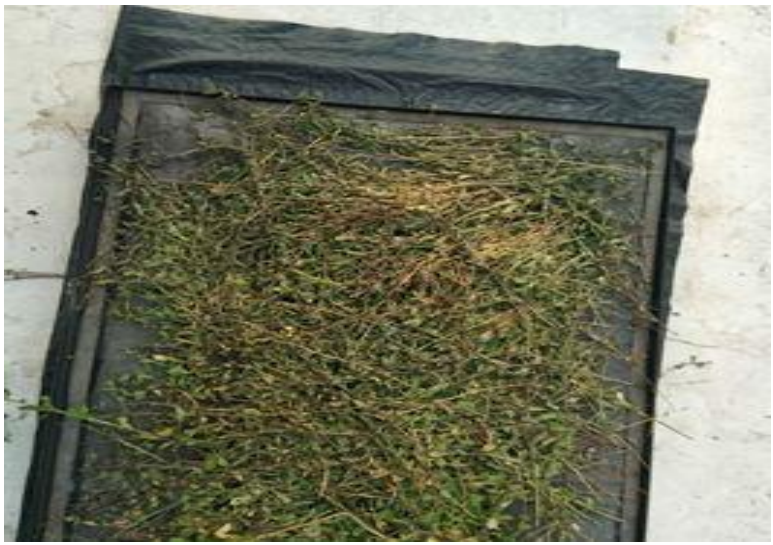

The following conclusions were drawn from the experimental studies and research work done on performance of solar tunnel dryer, for drying of mint leaves:

During the period of no load testing the maximum temperature inside the solar tunnel dryer without reflector was found to be $67^{\circ} \mathrm{C}$ and minimum temperature was $35^{\circ} \mathrm{C}$. It was observed that the maximum temperature inside the solar tunnel dryer with reflector was $73^{\circ} \mathrm{C}$ while minimum temperature obtained was $39^{\circ} \mathrm{C}$. The maximum and minimum corresponding ambient temperature was measured as $25^{\circ} \mathrm{C}$ and $20^{\circ} \mathrm{C}$ respectively.
From the experimental results obtained it is observed that there is an increment of $42^{\circ} \mathrm{C}$ temperature inside dryer without reflector and $48^{\circ} \mathrm{C}$ temperature inside solar tunnel dryer with reflector as compared to outside ambient temperature.

During the full load testing the maximum temperature obtained inside the developed solar tunnel dryer without reflector was $64^{\circ} \mathrm{C}$ while the minimum temperature obtained was $38^{\circ} \mathrm{C}$. Similarly, the maximum temperature obtained inside the solar tunnel dryer with reflector was $73^{\circ} \mathrm{C}$ and minimum temperature obtained was $42^{\circ} \mathrm{C}$. The maximum ambient atmospheric temperature was measured as 
$32^{\circ} \mathrm{C}$ and minimum ambient temperature was $28^{\circ} \mathrm{C}$ respectively. From the experiment it was observed that there is an increment of 23 ${ }^{\circ} \mathrm{C}$ inside the solar tunnel dryer and there was an increment of $41{ }^{\circ} \mathrm{C}$ inside solar tunnel dryer with reflector as compared to the ambient temperature.

Inside the solar tunnel dryer, during full load testing, the value of maximum and minimum relative humidity outside the solar dryer without reflector was measured as $46 \%$ and $28 \%$ respectively. During the solar tunnel dryer with reflector the maximum and minimum value of outside relative humidity was observed as $28 \%$ and $16 \%$ respectively. So finally, the maximum and minimum relative humidity value outside solar dryer without reflector was $46 \%$ and $28 \%$. For solar dryer with reflector the maximum and minimum value of relative humidity was $28 \%$ and $16 \%$ respectively. The time required to dry mint leaves in solar dryer with reflector was $14 \mathrm{~h}$, in referenced dryer was $15 \mathrm{~h}$ and in open sun drying was $19 \mathrm{~h}$. There is a variation in drying time in both dryer and open sun drying due to the temperature differenced.

For the colour determination the instrument used was Hunter lab colorimeter which showed $\mathrm{L}^{*}$ value for dried mint leaves in open sun drying, solar tunnel drying, and solar tunnel drying with reflector was measured as 31.68, 26.03 and respectively. In open sun, solar tunnel drying and solar dryer with reflector the $a^{*}$ value for dried mint leaves was observed as 1.26, 1.54 and -4.23 respectively. The $b^{*}$ value for the dried mint leaves in open sun drying, solar tunnel drying and solar tunnel drying with reflector was measured as 1.46, 3.16 and respectively.

\section{References}

Aiswarya, M.S. and Divya, C.R. 2015. Economic analysis of solar dryer with pcm for drying agricultural products. International Research Journal of Engineering and Technology 4 : 19481953.

Akpinar, E.K. 2010. Drying of mint leaves in a solar dryer and under open sun: modelling, performance analyses. Energy conversion and management 51 : 2407-2418.

Arjoo, Yadvika and Yadav, Y. K. 2017. Performance evaluation of solar tunnel dryer for drying of Garlic. Current Agriculture Research Journal 5 : 220226.

Chaudhari, Harajibhai, Ramesh, Gora, Alok, Modi, V.M. and Chaudhari, Hitesh 2018. Economic Analysis of Hybrid Solar Dryer for Ginger Drying. International Journal of Current Microbiology and Applied Sciences 7: 2725-2731.

Doymaz, I. 2006. Thin-layer drying behaviour of mint leaves. Journal of Food Engineering 74 : 370-375.

Hossain, M.A., Amer, B.M.A. and Gottschalk, K. 2008. Hybrid solardryer for quality dried tomato. Drying Technology 26 : 1591-1601.

Hossain, M.A. and Bala B.K. 2007. Drying of hot chilli using solar tunnel drier. Solar Energy 81 : 85-92.

Hossain, M.A., Woods, J.L. and Bala, B.K. 2005. Optimisation of solar tunnel drier for drying of chilli without colour loss. Renewable Energy 30 : 729-742.

Janjai, S. and Tung, P. 2005. Performance of solar dryer using hot air from roofintegrated solar collectors for drying herbs and spices. Renewable Energy 30 : 2085-2095.

Kadam, D.M., Goyal , R.K., Singh, K.K. and Gupta, M.K. 2011. Thin layer convective drying of mint leaves. Journal of Medicinal Plants Research 5 : 164-170.

Kalbande, S.R., Jadhav, P., Khambalkar 
V.P. and Deshmukh, S. 2017. Design of solar dryer assisted with reflector for drying of medicinal crops. International Journal Current Microbial and Applied Science 6: 170-184.

Kumar, A., Kumar, V., Khan, K. and Kumar, A. 2017. Experimental Investigation on Drying of mint leaves (M. pulegium) in solar tunnel dryer. International Journal Pure and Applied Bioscience 5: 682-689.

Lavanaya, R. 2018. Development and comparative performance evaluation of solar dryer with the use of different covering materials. M.Tech. thesis submitted to Maharana Pratap University of Agriculture and Technology, Udaipur, Rajasthan.

Minj, Pankaj, Mahilong Sing kipoo kiran, Raj Johan Diamond and Sonboier Khilendra. 2018. Studied on some Drying characteristics of amla. International Journal of Current
Microbiology and Applied Science 7: 2213-2118.

Navale, S.R., Harpale, V.M. and Mohit, K.C. 2015. Comparative study of open sun and cabinet solar drying for fenugreek leaves. International Journal of Renewable Energy Technology Research 4: 1-9.

Perera, C.O.2005. Selected quality attributes of dried foods. Drying Technology. 23 : 717-730.

Poonia, S., Singh, A.K., Santra, P. and Jain, D. 2017. Performance evaluation and cost economics of a low cost solar dryer for Ber (Zizyphus mauritiana) fruit. Agricultural Engineering Today 41 : 25-30.

Sevda, M.S., Rathore, N.S. and Singh, P. 2004. Techno-economics of solar tunnel dryer -A case study. Journal of Agricultural Engineering 41 : 13-17

\section{How to cite this article:}

Ronak Bagri and Deepak Sharma. 2021. Design, Development and Performance Evaluation of a Solar Tunnel Dryer with Reflector for Drying of Agro Food Products. Int.J.Curr.Microbiol.App.Sci. 10(02): 3263-3277. doi: https://doi.org/10.20546/ijcmas.2021.1002.359 